\title{
Preliminary Report on the Flora of Southern Hidaka, Hokkaido (Yezo). X. ${ }^{1}$
}

\author{
By
}

\section{Hiroshi Hara.}

Received June 1, 1935.

\section{Aquifoliaceae.}

Ilex L.

310(1)*Ilex macropoda Miqueu in Ann. Mus. Bot. Lugd.-Bat. III, p. 105 (1867).-Tatew., Veg. Apoi p. 95 (1928).-Miyabe et Kudo, Icon. Essent. For. Tree. Tokk. III, p. 5, tab. 63 (1929).-NakaI, Veg. Apoi p. 58 (1930). Syn. Ilex dubia Treu var. macropoda Loesender, Monogr. Aquifol. I, p. 487

(1901); in Mitt Deut. Dendr. Ges. XXVIII, p. 58 (1919).-Matsumura, Ind. Pl. Jap. II-2, p. 315 (1912).

Nom. Jap. Awo-hada.

Hab. in forests of Mt. Apoi, ete. Fl. Jun.

Dist. Kyushu, Shikoku, Honshu, Yezo and Korea.

311 (2)*Ilex radicans NAKAI, Veg. Apoi p. $37 \& 58$ (1930) nom. seminud. Syn. Ilex crenata (non Thunberg) auct. plur. quoad pl. ex Kuriles, Yezo et Sachalin.

Ilex crenata Thunb. subsp. radicans Tatewaki in Acta Phytotax. et Geobot. II, p. 243 (1933) sine descrip.

Ab Ilex crenata cum rhizomatibus semper repentibus, caulibus humilioribus basi arcuato-ascendentibus differt.

Nom. Jap. Hai-inutsuge (NAKAI).

Hab. at the top and in forests at the foot of Mt. Apoi. Fl. middle Jul.-early Aug.

Dist. Middle \& Northern Honshu, Yezo, S. Kuriles and S. Saghalien.

The size and shape of leaves are variable as in Ilex crenata. The largest specimen which I saw in Yezo attained about $1.5 \mathrm{~m}$. high.

312(3)*Ilex rugosa Fr. Sснмidт, Reis. Amur. u. Sachal. p. 122, t. 3, f. 1-7 (1868).-Loesener, Monogr. Aquifol. I, p. 420 (1901).-Matsumura, Ind. Pl. Jap. II-2, p. 317 (1912).-Loesener in Mitt. Deut. Dendr. Ges. XXVIII, p. 50 (1919).-Kudo, Rep. Veg. N. Saghal. p. 176 (1924).-Tatew., Veg. Apoi p.

1) As regards signs and abbreviations, confer Vol. XLVIII, p. 688 (1934) of this Magazine. 
95 (1928).-Nakai, Veg. Apoi p. 58(1930).-Komarov et Klob.-Alisova, Key Pl. Far East. Reg. USSR. II, p. 717, t. 215 (1932).

Nom. Jap. Tsuru-tsuge.

Hab. in forests of Mt. Apoi, etc. Fl. Jun.

*var. vegeta HARA, var. nov.

Syn. Ilex Fauriei (non Makino) NakaI, Veg. Apoi p. 29 \& 58 (1930).

Caulis ascendens. Folia latiora quam typica, usque ad $4 \mathrm{~cm}$. longa 2.3 cm. lata.

Nom. Jap. Maruba-tsurutsuge (nov.).

Hab. in forests at the foot of Mt. Apoi (T. NakaI-Aug. 1928-type).

Dist. sp. Middle \& Northern Honshu, Yezo, Kuriles and Saghalien.

313(4)*Ilex Sugeroki Maximowicz in Mém. Acad. Imp. Sci. St.-Pétersb. ser. 7, XXIX-3, p. 22 \& 35, t. 1, f. 7 (1881).-Matsumura, Ind. Pl. Jap. II-2, p. 318 (1912) pro major. part.-NakaI, Veg. Apoi p. 58 (1930).

Syn. Ilex Sugeroki f. brevipedunculata Maximowicz, l. e. p. 36, t. 1, f. d-e (1881).-Loesener, Monogr. Aquifol. I, p. 134 (1901); in Mitt. Deut. Dendr. Ges. XXVIII, p. 12 (1919).

Ilex Sugeroki subsp. brevipedunculata Makino in Bot. Mag. Tokyo

XXVII, p. 78 (1913).-TATEw., Veg. Apoi p. 95 (1928).

Nom. Jap. Akami-no-inutsuge (Mryabe).

Hab. in the upper part of Mt. Apoi.

Dist. Honshu, Yezo and S. Kuriles.

\section{Celastraceae.}

Celastrus L.

314(1)*Celastrus strigillosus NAKAI in Bot. Mag. Tokyo XL, p. 492 (1926); Veg. Apoi p. 58 (1930).

Syn. Celastrus articulatus (non Thunb.) Tatew., Veg. Apoi p. 95 (1928).

Nom. Jap. Oni-tsuru-umemodoki (NAKAI).

Hab. in the lower part of Mt. Apoi, ete. Fl. Jun.

Dist. Honshu, Yezo and Saghalien.

Evonymus L.

$315^{(2) * E v o n y m u s ~ a l a t u s ~ S i e b o l d, ~ S y n o p . ~ P l . ~ O e c o n . ~ J a p . ~ p . ~} 49$ (1830).T. ITô in Bot. Mag. Tokyo XIV, p. 167 (1900).

Syn. Celastrus alatus Thunberg, Fl. Jap. p. 98 (1784).

var. apterus REGEL, Tent. Fl. Ussur. p. 41, t. 7. f. 2-3 (1861).

Syn. Euonymus alata $\gamma$. pubescens Maximowicz in Bull. Acad. Imp. Sci. St.-Pétersb. XXVII, p. 454 (1881) pro parte.-Matsumura, Ind. Pl. Jap. II-2, p. 320 (1912).-Miyabe et Miyake, Fl. Saghal. p. 92 
(1915).

Euonymus striata Makino var. pubescens Makino in Bot. Mag. Tokyo XXV, p. 230 (1911).

Evonymus striata Loesn. var. hirta Kordzumi in Bot. Mag. Tokyo XXXIX, p. 11 (1925).

Nom. Jap. Ke-komayumi (Makino 1911).

Hab. in the upper part of Mt. Horoman, Sanushibe (Samani), ete.

var. pilosus (KoIDzumi) Hara, comb. nov.

Syn. Euonymus alata $\gamma$. pubescens Maximowicz, 1. c. pro parte.

Evonymus striata Loesn. subsp. alata KoIDz. var. pilosa KoIdz., l. c. (1925).

Nom. Jap. Ke-nishikigi (KoIdzumi 1925).

Hab. near Horoman and along Nikanbetsu R.

The specimens of our district have narrowly winged branches and leaves pubescent along underside veins.

*var. subtriflorus Franchet et Savatier, Enum. Pl. Jap. II, p. 311 (1876) (subtriflora).

Syn. Celastrus striatus Thunberg, Fl. Jap. p. 98 (1784).

Euonymus subtriflorus Blume, Bijdr. Fl. Nederl. Ind. 17, p. 1147 (1826).

Euonymus alata var. subtriflora Maximowicz in Bull. Acad. Imp. Sci. St.-Pétersb. XXVII, p. 454 (1881).

Euonymus striata Loesener in ENGL., Bot. Jahrb. XXX, p. 463 (1902) excl. specim.-Kordzum in Bot. Mag. Tokyo XXXIX, p. 10 (1925).

Euonymus alatus Sieb. var. striatus Makino in Bot. Mag. Tokyo XXI, p. 138 (1907).-Matsumura, 1. c. (1912).-Tatew., Veg. Apoi p. 96 (1928).-Nakai, Veg. Apoi p. 58 (1930).

Euonymus striata Loesn. var. subtriflora SchneIder, Ill. Handb. Laubholzk. II, p. 172 (1907).

Euonymus striata Makino in Bot. Mag. Tokyo XXV, p. 229 (1911).

Nom. Jap. Ko-mayumi.

Hab. in Mt. Apoi (rare), Mt. Horoman, Mt. Ruchishi, etc. Fl. Jun.

Dist. sp. Kyushu, Shikoku, Honshu, Yezo, Kuriles, Saghalien, Korea, China, Manchuria, Ussuri and Amur.

$316^{(3)}$ *Evonymus macropterus Ruprecht in Bull. Phys. Math. Acad. St.Pétersb. XV, p. 359 (1857).-Matsumura, Ind. Pl. Jap. II-2, p. 322 (1912).Fedtschenko, Fl. Aziat. Ross. V, p. 25, f. 11 (1914).-Kudo, Rep. Veg. N. Saghal. p. 176 (1924).-Tatew., Veg. Apoi p. 96 (1928).-Nakai, Veg. Apoi p. 59 (1930). 
Nom. Jap. Hiroha-no-tsuribana.

Hab. in Mt. Apoi, Mt. Horoman, ete. Fl. Jun.

Dist. Honshu, Yezo, Kuriles, Saghalien, Korea, Manchuria and Amur. 317(4)**Evonymus oxyphyllus Miquel in Ann. Mus. Bot. Lugd.-Bat. II, p. 86 (1865).-Matsumura, Ind. Pl. Jap. II-2, p. 322 (1912).-Koidzumi in Matsumura, Icon. Pl. Koisik. I, p. 77, pl. 39 (1912).-Prain in Curtis, Bot. Mag. t. 8639 (1915).-Mryabe et Kudo, Icon. Essent. For. Tree. Hokk. III, p. 7, tab. 64 (1929).

Syn. Euonymus yesoensis Kordzumi, Fl. Symb. Or.-Asia. p. 13 (1930).

Nom. Jap. Tsuribana.

Hab. at the foot of Mt. Apoi (the Horoman side), Mt. Ruchishi, etc. Fl. Jun.

Dist. Kyushu, Shikoku, Honshu, Yezo, Kuriles and Korea.

$318^{(5) * E v o n y m u s ~ p l a n i p e s ~ K o e m n e ~ i n ~ M i t t . ~ D e u t . ~ D e n d r . ~ G e s . ~ X V I, ~ p . ~}$ 62, f.'1. A (1906).-Schneider, Ill. Handb. Laubholzk. II, p. 176 (1907).Tatew., Veg. Apoi p. 96 (1928).-Nakai, Veg. Apoi p. 59 (1930).

Syn. Euonymus latifolius Scop. var. planipes Koenne in Gartenfl. LIII, p. 29, f. 12 (1904).

Euonymus oxyphylla Miq. var. Kuenbergii Honda in Bot. Mag. Tokyo XLVII, p. 297 (1933).

Nom. Jap. Ô-tsuribana, Nikkô-tsuribana (HoNDA).

Hab. in the lower part of Mt. Apoi and along Horoman R.

Dist. Honshu, Yezo, Kuriles, Korea and Manchuria.

$319^{(6)}$ Evonymus radicans Siebold ex Miquel in Ann. Mus. Bot. Lugd.Bat. II, p. 86 (1865) pro syn.; III, p. 202, no. 127 (1867); Prol. Fl. Jap. p. 366 \& p. 376 (1866-67).-Franchet et Savatier, Enum. Pl. Jap. I, p. 79 (1874).-Maximowicz in Bull. Acad. Imp. Sci. St.-Pétersb. XXVII, p. 441 (1881).-Reirder in Sargent, Trees and Shrubs I, p. 129 (1903).

Syn. Euonymus japonicus Thunb. var. radicans Miquel in Ann. Mus. Bot.

Lugd.-Bat. II, p. 86 (1865).-NAKAI, Fl. Korea. I, p. 123 (1909).-

Matsumura, Ind. Pl. Jap. II-2, p. 321 (1912).

Nom. Jap. Tsuru-masaki.

Hab. Saruru.

**var. vegetus ReIIDer in SARgent, l. c. pl. LXV (1903).

Nom. Jap. Maruba-tsurumasaki (nov.).

Hab. at the foot of Mt. Apoi.

Dist. sp. Liukiu, Kyushu, Shikoku, Honshu, Yezo and Korea.

$320^{(7) * E v o n y m u s ~ S i e b o l d i a n u s ~ B l u m e, ~ B i j d r . ~ F l . ~ N e d e r l . ~ I n d . ~ 17, ~ p . ~} 1147$ (1826). 
var. megaphyllus HARA, var. nov.

Syn. Euonymus yedoensis (non Koenne) NakaI, Veg. Apoi p. 22 \& 59 (1930).

Ab var. yedoensis Hara (E. yedoensis Koenne 1904) ramis brunneoochraceis differt.

Nom. Jap. Yezo-ôba-mayumi (nov.).

Hab. at the foot of Mt. Apoi. Fl. Jun.

Dist. sp. Kyushu, Shikoku, Honshu, Yezo, Saghalien, Korea, China and Manchuria.

This plant is exceedingly variable in all respects, and the characteristics by which KoEHne distinguished several species do not serve in the field. The size and shape of leaves, the hairiness on their underside veins, the length of the filaments and the colour of the arillus change by individuals. The character whether the arillus has an open aperture or not is also inconstant even on the same tree. So, to my mind, Evonymus Sieboldianus Blume, E. Vidalii Franch. et Sav., E. yedoensis Koehne, E. hians Koenne and $E$. semiexserta KoEHNe should be regarded as different forms of a single species.

$321^{(8)}$ Evonymus tricarpus Koidzumi in Matsumura, Icon. Pl. Koisik. III, p. 77, pl. 184 (1916) (tricarpa).

Syn. Evonymus sachalinensis Maxim. var. tricarpa Kudo in Rep. Exper. For. Kyushu Imp. Univ. I, p. 76 (1931).

Nom. Jap. Murasaki-tsuribana (Matsumura 1886), Kuro-tsuribana (KoIDz. 1916).

Hab. in the upper part of Mt. Rakko.

Dist. Middle \& Northern Honshu, Yezo and Saghalien.

This species is conspicuous in the field by having the leaves whose nerves are strikingly impressed on the upper surface.

\section{Staphyleaceae.}

Staphylea L.

322(1)*Staphylea Bumalda A. P. de Candolle, Prodr. II, p. 2 (1825).Tatew., Veg. Apoi p. 96 (1928).-Nakai in Bot. Mag. Tokyo XLIV, p. 17 (1930).

Syn. Bumalda trifolia Tinunberg, Nova Gen. Pl. II, p. 63 (1783); Fl. Jap. p. 114 (1784).

Staphylea Bumalda Siebold et Zuccarini ex Miquel in Ann. Mus. Bot. Lugd.-Bat. III, p. 93 (1867).-Matsunura, Ind. Pl. Jap. II-2, p. 324 (1912).-Nakai, Veg. Apoi p. 59 (1930). 
Nom. Jap. Mitsuba-utsugi.

Hab. at the foot of Mt. Apoi. Fl. Jun.

Dist. Kyushu, Shikoku, Honshu, Yezo, Korea, Manchuria and China.

\section{Aceraceae.}

Acer L.

323(1)*Acer amoenum Carrière in Rev. Hort. XXXIX, p. 280 (1867).NakaI in Bot. Mag. Tokyo XLVI, p. 610 (1932).

Syn. Acer palmata subsp. septemlobum KoIdzumi, Rev. Acer. Jap. (in Journ. Coll. Sci. Imp. Univ. Tokyo XXXII-1) p. 46, t. XXVII (1911) excl. syn. nonnul.

Acer euseptemlobum KoIdzumi in Bot. Mag. Tokyo XXXIX, p. 306 (1925).

Acer sanguineum var. euseptemlobum KoIdzumi in Bot. Mag. Tokyo XLIII, p. 382 (1929).

Acer sanguineum var. amoenum KoIdzumi in Acta Phytotax. et Geobot. III, p. 148 (1934).

Nom. Jap. $\hat{O}$-momiji.

Hab. in Mt. Apoi, ete.; common.

Dist. Honshu and Yezo.

The mode of serration is variable and some show an intermediate form between this species and $A$. ornatum.

$324^{(2) * *}$ Acer cissifolium C. Koch in Ann. Mus. Bot. Lugd.-Bat. I, p. 252 (1864) .-Koidzumi, Rev. Acer. Jap. p. 26, tab. XV (1911).-Matsumura, Ind. Pl. Jap. II-2, p. 326 (1912).-Mryabe et Kudo, Icon Essent. For. Tree. Hokk. III, p. 19, tab. 70 (1930).

Syn. Negundo cissifolium Siebold et Zuccarini in Abhandl. math.-phys.

Kl. Akad. Wiss. Muenchen IV-2, p. 159 (1845).

Nom. Jap. Mitsude-kaede.

Hab. along Horoman R., Samani, Mt. Ruchishi, etc.

Dist. Kyushu, Shikoku, Honshu and Yezo.

$325^{(3)}$ *Acer japonicum Thuniserg, Fl. Jap. p. 161 (1784).-Koidzumi, Rev. Acer. Jap. p. 39, tab. XXIV (1911).-Matsumura, Ind. Pl. Jap. II-2, p. 327 (1912).-Tatew., Veg. Apoi p. 96 (1928).-Nakai, Veg. Apoi p. 59 (1930).Miyabe et Kudo, Icon. Essent. For. Tree. Hokk. III, p. 15, tab. 68 (1930).

f. typicum Graf. v. Schwerin in Gartenfl. XLII, p. 708 (1893).-PAX in Engler, Pfl.-reich IV-163, Ileft 8, p. 24 (1902) pro var.

Nom. Jap. Hauchiwa-kaede. 
Hab. in Mt. Apoi, Shoya, etc.; common. Fl. late May-Jun.

Dist. sp. Honshu and Yezo.

Forma macrophyllum GraF v. Schwerin and f. angustilobum KoIDZUMI also occur in our district.

**var. stenolobum HaRA, var. nov.

Folia 5-9 $\mathrm{cm}$. longa $6-11 \mathrm{~cm}$. lata, ad medium palmati-lobata basi aperte cordata subtus in axillis nervorum albo-barbata, lobis 7-9 oblongis vel lanceolatis longe acuminatis inaequaliter duplicato-serratis mediis $2.5-5 \mathrm{~cm}$. longis 1-2 cm. latis. Samarae loculi $5 \mathrm{~mm}$. longi primo dense albo-lanuginosi; alae oblongae $1.5 \mathrm{~cm}$. longae angulo obtuso divergentes primo alhopubescentes.

Nom. Jap. Momiji-hauchiwa (nov.).

Hab. at the foot of Mt. Apoi (H. Hara-Jul. 8, 1933; no. 3147-type).

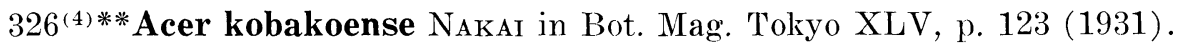
Syn. Acer japonicum Thunb. var. kobakoense Hara, mss.

Nom. Jap. Kobako-hauchiwa (NAKAI).

Hab. in Mt. Apoi, rare.

Endemic in Yezo.

This is nearest to $A$. japonicum, but differs from it by the almost simple big serration of the leaves.

327(5)*Acer Mayrii Graf v. Schwerin in Mitt. Deut. Dendr. Ges. X p. 58 (1901).-Pax in Engler, Pfl.-reich IV-163, Heft 8, p. 76 (1902).-Mayr, Frendl. Wald- u. Parkb. p. 440, f. 161 (1906).-Schneider, Ill. Handb. Laubholzk. II, p. 225, f. 150 a. g (1907).-TAkedA in Bot. Mag. Tokyo XXV, p. 26 (1911)-Tatew., Veg. Apoi p. 96 (1928)-Miyabe et Kudo, Icon. Ess. For. Tree. Hokk. III, p. 23, tab. 72 (1930).

Syn. Acer pictum var. typicum subvar. Mayri Kordzumi, Rev. Acer. Jap. p. 63 (1911) pro parte.

? Acer prictum var. Mayrii KoIdzumi, Fl. Symb. Or.-Asia. p. 54 (1930).-Nakai, Veg. Apoi p. 59 (1930).

Nom. Jap. Aka-itaya, Akame-itaya, Beni-itaya.

Hab. along Horoman R., Saruru-sandô, etc.

Dist. Northern Honshu and Yezo (northwards to prov. Kitami).

This maple differs from Acer mono by having more smooth bark, less hard wood, less branched and always glabrous branches, larger and broader leaves which are reddish when young, larger flowers, and larger samarae with often connivent wings.

$328^{(6)}$ Acer Miyabei Maximowicz in Bull. Acad. Imp. Sci. St.-Pétersb. 
XXXII, p. 485 (1888).-SARgent, For. Fl. Jap. p. 29, pl. IX (1894).-Koidzumi, Rev. Acer. Jap. p. 57, tab. XXXI (1911).-Matsumura, Ind. Pl. Jap. II-2, p. 328 (1912).-Miyabe et Kudo, Icon. Essent. For. Tree. Hokk. III, p. 25, t. 73 (1930).

Nom. Jap. Kurobi-itaya.

Hab. near Samani, rare.

Dist. Honshu and Yezo.

(To be continued.)

\title{
Contributio ad Cognitionem Flora Manshuricæe. IX.
}

auctore

\section{Masao Kitagawa.}

\author{
With 3 Text-figures.
}

Received July 19, 1935.

134) Primula hallaisanensis NakaI sp. nov. in sched. Herb. Imp. Univ.

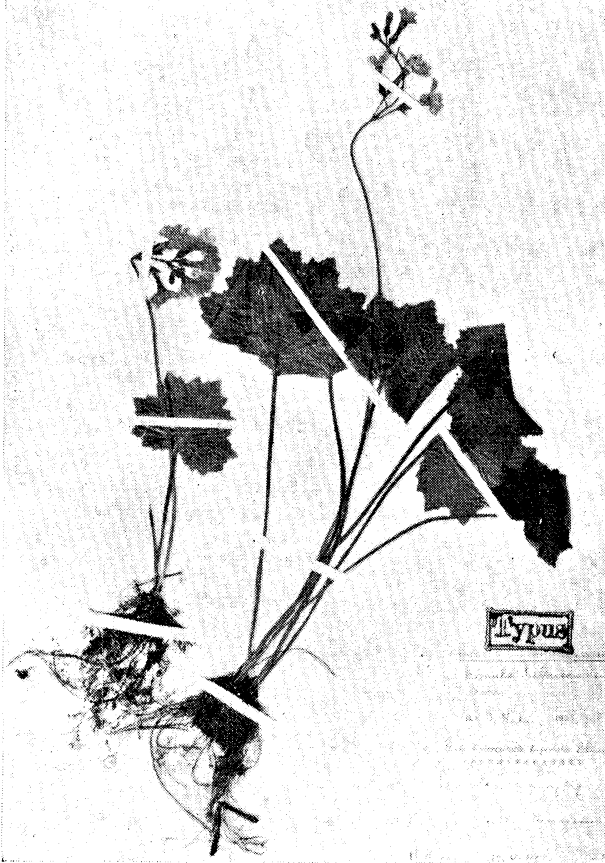

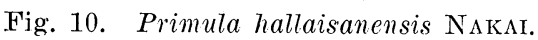

Tokyo.

Primula jesoana (non Miquel ) Nakai, Rep. Veg. Isl. Quelp. p. 72 (1914); MorI, Enum. Pl. Cor. p.283 (1922) pro parte, quoad pl. ex Quelp.

Rhizoma breve radices fibrosas fuscescentes numerosas dense emittens. Folia omnia radicalia longe petiolata; lamina orbiculato-reniformis apice obtusissima basi profundissime imbricato - cordata rarissime aperte cordata grossissime 7dentato-lobata lobis brevibus latissime deltoideis lobulatis lobulis deltoideis-latissime deltoideis denticulatis dentibus omnibus apice mucronulatis crasse herbacea subpalmatim 7-nervata supra viridis im- 